\title{
Reproductive traits in dolphinfish Coryphaena hippurus Linnaeus, 1758 along the coastal waters of Karnataka, south-eastern Arabian Sea
}

\author{
K. ASSANA, MRIDULA RAJESH AND K. M. RAJESH* \\ Department of Fisheries Resources and Management, College of Fisheries, Kankanady, Mangaluru - 575002 \\ Karnataka, India \\ ${ }^{*}$ Mangalore Research Centre of ICAR-Central Marine Fisheries Research Institute, Post Box No. 224, Hoige Bazar \\ Mangaluru, Karnataka - 575 001, India \\ e-mail: mridularajesh789@yahoo.co.in
}

\begin{abstract}
The maturity, sex ratio, gonadosomatic index (GSI) and fecundity of Coryphaena hippurus was investigated from 347 specimens collected along Karnataka coast, south-eastern Arabian Sea from August 2017 to May 2018. Overall sex ratio of 1:3.5 (male:female) indicated dominance of females in the fishery and differed significantly $(\mathrm{p}<0.05)$ in all the months, except in January, May and December. The fork length (FL) at 50\% maturity $\left(\mathrm{Lm}_{50}\right)$ was estimated at $47.5 \mathrm{~cm}$ for both males and females. The pattern of GSI and maturity stages suggests peak spawning activity in August-September. However, the incidence of fishes capable of spawning all through the year in varied proportions implied that spawning activity occurs throughout the year. The absolute fecundity estimates varied from 1,00,298 eggs for a female of $53.5 \mathrm{~cm}$ FL to $6,15,267$ eggs for female of $113 \mathrm{~cm}$ FL with an average fecundity of 3,18,446 eggs per female. The fecundity of fish increased with body length and weight as well as with gonad weight. The biological information on maturation, reproductive cycle, spawning periodicity and fecundity of C. hippurus in the tropical Arabian Sea could be useful for developing appropriate management tools and conservation strategies for this commercially important fish species.
\end{abstract}

Keywords: Fecundity, Gonadosomatic index, Mahi mahi, Sex ratio, Size at first maturity

\section{Introduction}

The genus Coryphaena under the monogeneric family Coryphaenidae comprises two species viz., Coryphaena hippurus Linnaeus, 1758 and Coryphaena equiselis Linnaeus, 1758. C. hippurus commonly called as dolphinfish or mahi mahi is a highly migratory epipelagic fish found all over the world in tropical, subtropical and temperate waters (Zuniga-Flores et al., 2011; Molto et al., 2020) and are more common in temperatures between 21 and $30^{\circ} \mathrm{C}$ (FAO, 2019). Globally, the harvests of dolphinfish have increased by 10 folds from 0.01 million in 1950s to 0.1 million t from 2008 onwards (FAO, 2019). This fish is less susceptible to overfishing due to its remarkable fast growth and high turnover (FWRI, 2008; Molto et al., 2020). Growth rates of this fish can be as high as $4 \mathrm{~mm}$ per day, but vary considerably (Oxenford and Hunte, 1983) depending on location and season (Oxenford, 1999). They are included under the category 'least concern' in the IUCN Red list (Collette et al., 2011). C. hippurus is considered as an economically important fish species as it supports artisanal, recreational and commercial fisheries in several regions (Lasso and Zapata, 1999; Olson and Galvan-Magana, 2002). C. hippurus is an apex predator, consuming approximately $5-6 \%$ of its body weight each day and removes considerable amount of tertiary production from the ecosystem (Olson and Galvan-Magana, 2002; Guzman et al., 2015).

C. hippurus is one of the major fishery resources, forming about $2.6 \%$ of total large pelagic fish landed along Karnataka coast in 2018 (CMFRI, 2018). They are fished mainly by gillnets and troll lines operated from trawlers, purse seines and other fishing gears such as ring seines and shore seines. Information on reproductive biology is an essential component in the study of the population dynamics and biology of any fish species (Hunter et al., 1992; Murua and Saborido-Rey, 2003). Several investigations were conducted to study the reproductive biology of $C$. hippurus from various parts of the world (Arocha et al., 1999; Castro et al., 1999; Wu et al., 2001; Zuniga-Flores et al., 2011; Furukawa et al., 2012; Santos et al., 2014; Gatt et al., 2015; Brewton et al., 2016). Despite the fact that $C$. hippurus is a commercially important fish contributing significantly to the Indian marine fishery, a detailed report on reproductive biology of C. hippurus is not available from the tropical Arabian Sea, except a few reports focusing on some aspects of reproductive biology (Rajesh et al., 2016; Vinod Kumar et al., 2017; Saroj et al., 2018). In this study, maturation, 
seasonality of spawning and reproductive potential of C. hippurus was investigated in detail along Karnataka coast, south-eastern Arabian Sea, focusing on specific indicators such as sex ratio, maturity stages, length at first maturity $\left(\mathrm{Lm}_{50}\right)$, gonadosomatic index (GSI) and fecundity.

\section{Materials and methods}

The present study was based on a sample of 347 individuals of C. hippurus, having 30.0 to $123.0 \mathrm{~cm}$ fork length (FL), which included 77 males and 270 females. Fish samples landed from gillnets, hooks and lines operated from trawl boats and purse seines were collected weekly from the two major fishing harbours at Mangaluru $\left(12.853^{\circ} \mathrm{N} ; 74.833^{\circ} \mathrm{E}\right)$ and Malpe $\left(13.347^{\circ} \mathrm{N} ; 74.701^{\circ} \mathrm{E}\right)$ located along the south-eastern Arabian Sea during August 2017 to May 2018. The samples could not be collected during June and July due to the monsoon fishing ban for the operation of mechanised fishing vessels. The collected specimens were placed immediately in an insulated icebox and transported to the laboratory of the Mangalore Research Centre of ICAR-Central Marine Fisheries Research Institute (ICAR-CMFRI), Mangalore, India for further analysis.

The FL and body weight of all the fishes were measured nearest to $0.1 \mathrm{~cm}$ and $0.1 \mathrm{~g}$ accuracy respectively. Gonads were carefully dissected out and the weight was measured to the nearest $0.01 \mathrm{~g}$. Maturity stages of the fishes were classified based on the space occupied by the testis or ovary and their macroscopic and microscopic appearance, into five stage maturity scale given by Brown-Peterson et al. (2011) as immature, developing, spawning capable, regressing and regenerating. The ovaries were preserved in customised Gilson's fluid (Bagenal and Braum, 1978) for the estimation of fecundity. The sex ratio of the fish was calculated and Chi-square test was used to test significant difference from the expected sex ratio of 1:1. The length at first maturity $\left(\mathrm{Lm}_{50}\right)$, defined as FL at which $50 \%$ of the fishes reached sexual maturity was estimated from the logistic equation (King, 2007) as follows:

$$
\mathrm{P}=1 /\left(1+\exp \left[-\mathrm{r} \times\left(\mathrm{FL}_{-} \mathrm{L}_{\mathrm{m}}\right)\right]\right)
$$

where, $\mathrm{P}$ is the proportion of mature individuals in a length class, FL is fork length, $\mathrm{r}$ (intercept) and $\mathrm{L}_{\mathrm{m}}$ (slope) are two parameters of the logistic model. These two parameters were estimated using the Non-Linear Regression SOLVER routine from the ratio of reproductive to non-reproductive fish groups.

Gonadosomatic index (GSI) was calculated for males and females separately considering the gonad weight and total weight of fish using the equation: GSI $=[\mathrm{Gonad}$ weight/(Body weight-Gonad weight) $] \times 100$. Reproductive pattern of C. hippurus, was assessed by plotting estimated GSI values during different months. During the annual cycle analysed, the occurrence of spawning was inferred with both the GSI peaks and the frequency of specimens capable of spawning according to the maturity phases found during different months.

The maturing and spawning condition of C. hippurus is characterised by the presence of a mode in the largest oocytes of at least $0.6 \mathrm{~mm}$ diameter (Massuti and MoralesNin, 1997) and hence, fecundity was estimated from mature oocyte of $>0.6 \mathrm{~mm}$ from 19 females, following gravimetric method as the product of gonad weight and oocyte density (Murua et al., 2003). Three to five subsamples from various parts of the ovary lobe were taken and analysed. Each sub sample was weighed to the nearest $0.001 \mathrm{~g}$ and then dispersed with a fine brush. Number of oocytes was measured with a grid. Fecundity was calculated using the formula:

$\mathrm{F}=[$ Gonad weight $\times($ Subsample egg count $/$ Gonad subsample weight)]

The relationship between fecundity and different variables like fork length, fish weight and gonad weight were worked out using the empirical equation $\mathrm{F}=a \mathrm{X}^{b}$ where; F = Fecundity; $a=$ Constant; $\mathrm{X}=$ Variable (fish length, fish weight or ovary weight) and $b=$ Correlation coefficient. The constants ' $a$ ' and ' $b$ ' were derived by the method of linear least squares.

\section{Results and discussion}

Among the 347 C. hippurus samples collected, female represented $270(77.81 \%)$ and male 77 numbers $(22.19 \%)$ with an overall sex ratio of 1:3.5 (male:female) indicating dominance of females in the fishery. The results of Chi-square $\left(\chi^{2}\right)$ test indicated that the sex ratio differed significantly $(\mathrm{p}<0.05)$ in almost all the months except in January, May and December (Table 1). Similar female dominated disparity in sex ratio in C. hippurus has been documented from other parts of the world (Molto et al., 2020). A sex ratio (male:female) of 1:3 has been reported from Puerto Rico (Erdman, 1976) and Barbados (Oxenford, 1985). Similarly, sex ratio of 1:2.3, 1:2.05, $1: 1.9,1: 1.8,1: 1.75$ and $1: 1.5$ with female dominance was reported from Puerto Rico (Bentivoglio, 1998), south-west coast of India (Rajesh et al., 2016), North Carolina waters (Rose and Hassler, 1974), Florida current (Oxenford, 1985), Saurashtra Coast of India (Saroj et al., 2018) and Maltese waters, Central Mediterranean (Gatt et al., 2015) respectively. Occurrence of more females in fishery could be due to the temporary migration undertaken for spawning rather than a real population differences in sex ratio (Oxenford, 1999). The temporal patterns of changes in sex ratios may also be due to sexual differences in 
Table 1. Sex-ratio of C. hippurus in different months along Karnataka coast, south-eastern Arabian Sea during August 2017-May 2018

\begin{tabular}{lllllll}
\hline Months & Total & Male & Male $\%$ & Female & Female $\%$ & Chi-square $\left(\chi^{2}\right)$ value \\
\hline January & 17 & 6 & 35.3 & 11 & 64.7 & 0.73 \\
February & 69 & 19 & 27.5 & 50 & 72.5 & $6.96^{*}$ \\
March & 53 & 10 & 18.9 & 43 & 81.1 & $10.27^{*}$ \\
April & 13 & 5 & 38.5 & 8 & 61.5 & 0.34 \\
May & 16 & 3 & 18.8 & 13 & 81.3 & 3.12 \\
August & 45 & 6 & 13.3 & 39 & 86.7 & $12.10^{*}$ \\
September & 47 & 10 & 21.3 & 37 & 78.7 & $7.75^{*}$ \\
October & 51 & 9 & 17.6 & 42 & 82.4 & $10.68^{*}$ \\
November & 24 & 5 & 20.8 & 19 & 79.2 & $4.08^{*}$ \\
December & 12 & 4 & 33.3 & 8 & 66.6 & 0.67 \\
Total & 347 & 77 & 22.2 & 270 & 77.8 & 0.92 \\
\hline
\end{tabular}

"Significant at $5 \%$

migratory, spawning or other reproductive behaviours (Hunter and Macewicz, 1985). The dominance of females in the fishery recorded in the present study could be due to the pre-spawning migration of females and gathering behaviour of small sized fishes near floating objects as documented from previous studies (Rose and Hassler, 1974; Massuti and Morales-Nin, 1997).

The information on size at first maturity $\left(\mathrm{Lm}_{50}\right)$ is an important factor for sustainable management of the fishery resources as it indicates status of spawning stock biomass (SSB), which plays a vital role in the recruitment of fish. Maturity was determined based on five-stage scale for both female and male. The smallest female and male with mature gonads showed FL of $30.5 \mathrm{~cm}$ and $33.0 \mathrm{~cm}$ respectively. The estimated value of length at first maturity $\left(\mathrm{Lm}_{50}\right)$ for both male and female C. hippurus was $47.5 \mathrm{~cm}$ (Fig. 1a,b). Similar values of $\mathrm{Lm}_{50}$ was reported from earlier investigations by McBride et al. (2012) in the Florida Keys of the Atlantic Coast ( $45.2 \mathrm{~cm}$ for both sexes), Schwenke and Buckel (2008) in North Carolina (45.8 cm for female and $47.6 \mathrm{~cm}$ for male), Alejo-Plata et al. (2011) in the Mexican Pacific (48.38 cm and $50.57 \mathrm{~cm}$ for female

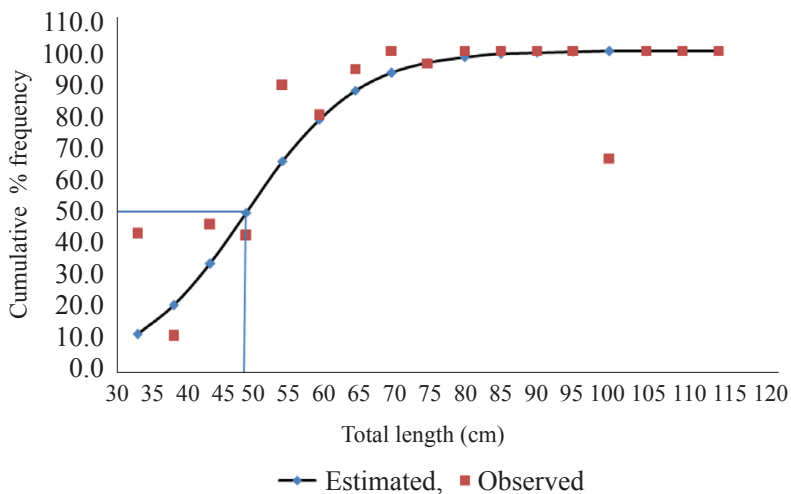

(a) and male, respectively) and Wu et al. (2001) in Taiwanese waters $\left(51.0 \mathrm{~cm}\right.$ for both the sexes). However, higher $\mathrm{Lm}_{50}$ values were reported by Massuti and Morales-Nin (1997) in the Island of Majorca, western Mediterranean $(54.5 \mathrm{~cm}$ for female and $61.8 \mathrm{~cm}$ for male), Gatt et al. (2015) in the Maltese waters, Central Mediterranean $(62.56 \mathrm{~cm}$ for female and $58.9 \mathrm{~cm}$ for male) and Santos et al. (2014) in Saint Peter and Saint Paul Archipelago, Brazil $(68.60 \mathrm{~cm}$ for female and $70.66 \mathrm{~cm}$ for male). Only $27.8 \%$ of female and $31.2 \%$ of male $C$. hippurus sampled were below the $\mathrm{Lm}_{50}$ which indicated that fishery is sustainable in Karnataka coast off south-eastern Arabian Sea. The variations noticed in $\mathrm{Lm}_{50}$ values from different regions could be due to the difference in temperature, quantity and quality of the food available for growth, method used to estimate maturity and the genetic difference (Diaz et al., 2010; McBride et al., 2012; Johnson et al., 2013; Maggio et al., 2018).

Mean GSI values of females varied from 0.82 to 6.02 with maximum values recorded in September (Fig. 2) and moderate values recorded during August and October to December. Similarly, high frequencies of spawning

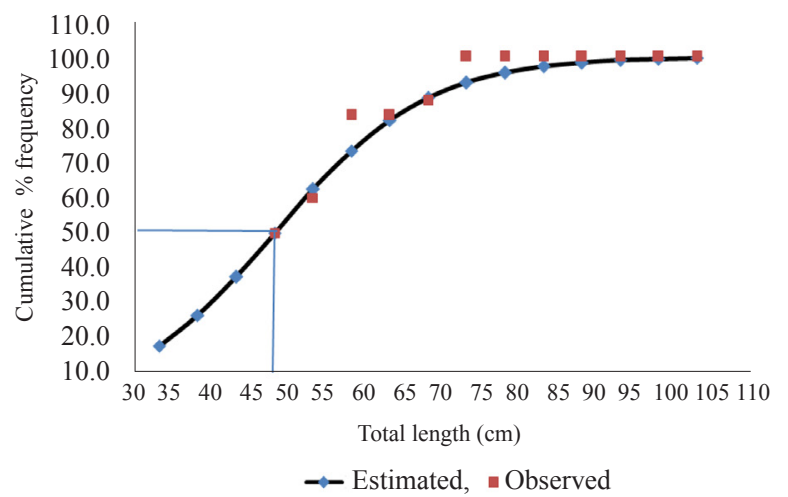

(b)

Fig. 1. Length at first maturity of (a) Female and (b) Male C. hippurus along Karnataka coast, south-eastern Arabian Sea during August 2017-May 2018 


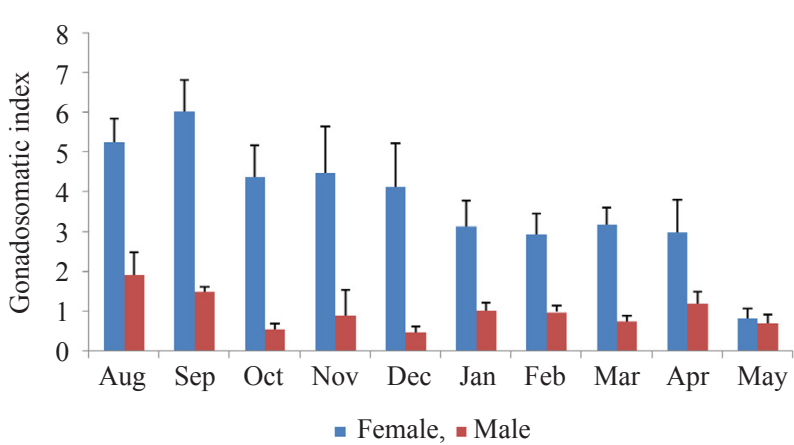

Fig. 2. Gonado-somatic index (GSI) $( \pm \mathrm{SE})$ of $C$. hippurus along Karnataka coast, south-eastern Arabian Sea during August 2017-May 2018

capable females were observed $(43.0 \%)$ in September (Fig. 3a). The incidence of spawning capable ovaries was noticed all through the year in varied frequencies (6.96 to $43.0 \%$ ). The mean GSI values of males varied from 0.47 to 1.92 with significantly higher values recorded in August and September (Fig. 2). The macroscopic and microscopic observations of the testicular maturity confirmed the occurrence of spawning capable individuals throughout the year (Fig. 3b) in different proportions (16.7-52.6\%) with maximum proportions during August (52.6\%). In the present study, the higher proportion of spawning capable males and GSI indicated that the peak spawning period of male (August) was slightly prior to that of female (September). This supports the findings of Zuniga-Flores et al. (2011) as they opined that males might initiate reproduction just before female.

Results of the present investigations confirmed the reproductive cycle in C. hippurus from tropical Arabian Sea, based on the evidence of GSI and presence of spawning capable fishes. The incidence of maximum GSI values and high frequencies of spawning capable fishes

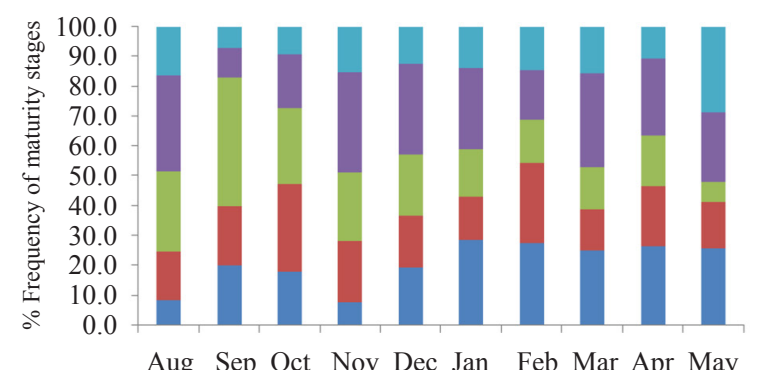

Aug Sep Oct Nov Dec Jan Feb Mar Apr May

= Regenerating, = Regressing, = Spawning capable, = Developing, = Immature

(a)

Fig. 3. Relative frequency of maturity phases of (a) Female and (b) Male C. hippurus along Karnataka coast, south-eastern Arabian Sea during August 2017-May 2018 (b)

confirmed that $C$. hippurus exhibited a peak spawning activity in August-September. Further, the presence of spawning capable fishes in varied proportions during all the months suggested that spawning occur throughout the year. Similar high reproductive activity of $C$. hippurus was reported earlier from Karnataka coast, south-west coast of India with varied minor spawning activity all through the year (Rajesh et al., 2016). The peak spawning period observed during the monsoon season coincided well with the slight reduction in water temperature and salinity with the peak monsoon showers in the study area. The peak spawning activity observed during the monsoon period (August-September) in the present study could be linked with the reduction in temperature from a peak water temperature of pre-monsoon summer months in the tropical Arabian Sea, south-west coast of India (Sushanth and Rajashekhar, 2014). In contrast, increased spawning activity was reported in female $C$. hippurus from southern Gulf of California with the rise in temperature from 25 to $30^{\circ} \mathrm{C}$ (Zuniga-Flores et al., 2011). On the other hand, almost year round spawning activity observed in lower proportion could probably be related to the deficiency of strong seasonality of environmental parameters, primarily the water temperature of tropical areas. C. hippurus is a (Massuti and Morales-Nin, 1997). Multiple spawning is a distinct reproductive strategy adapted by tropical and subtropical fish (Burt et al., 1988), probably to take advantage of the favourable environmental conditions for larval survival and recruitment (Massuti and Morales-Nin, 1997). A regional peak in spawning activity with year round spawning in varied proportion has been reported from various tropical regions (Cheung et al., 2008; Saroj et al., 2018). However, in temperate and subtropical regions, fish tend to synchronise spawning to the warm period of the year (Beardsley, 1967; Castro et al., 1999; Gatt et al., 2015; Molto et al., 2020). multiple spawner, spawns year round in tropical waters

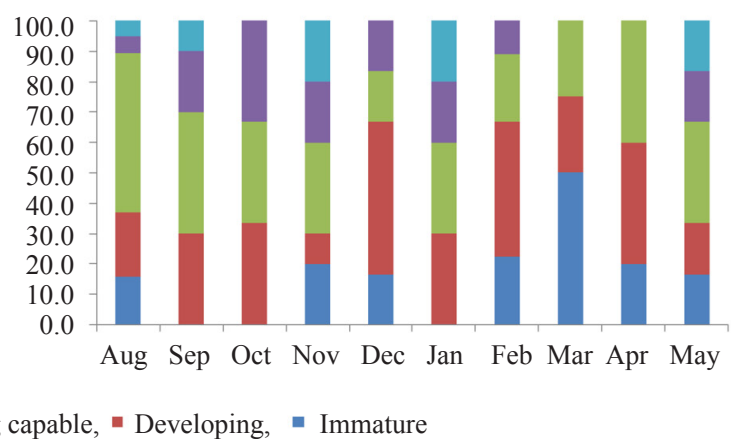


The estimated absolute fecundity per spawning event ranged from 1,00,298 eggs ( $53.5 \mathrm{~cm} \mathrm{FL)} \mathrm{to} \mathrm{6,15,267} \mathrm{eggs}$ (113 cm FL). The average fecundity was estimated at $3,18,446$ oocytes per female ( $\mathrm{SD} \pm 1,46,689)$. The relative fecundity (expressed as the number of ova per $g$ of fish weight) ranged from 94 to 373 oocytes, with a mean value of 179 ( $\mathrm{SD} \pm 13.9)$. The absolute fecundity recorded from other studies was comparable with the present findings. Chatterji and Ansari (1982) recorded 1,38,636 (55 cm TL) to $5,49,540$ ova ( $80 \mathrm{~cm} \mathrm{TL}$ ) with an average of $3,00,878$ along central west coast of India. Zuniga-Flores et al. (2011) estimated a range of $33,022(61.0 \mathrm{~cm} \mathrm{FL})$ to $7,30,555$ (111 cm FL) ova and an average of 2,79,383 in a study conducted at southern Gulf of California. Similarly, McBride et al. (2012) recorded batch fecundity ranging from 19,600 to $6,18,400$ eggs in female fish having fork length of 53.8 and $121.0 \mathrm{~cm}$ respectively from Florida waters. However, Beardsley (1967) has estimated a batch fecundity of 80,000-10,00,000 in Straits of Florida which is almost twice compared to the present study. In the same way, fecundity of $C$. hippurus from the East coast of Taiwan ranged from 2,78,413 for female measuring $42.0 \mathrm{~cm}$ FL to $23,48,463$ for female measuring $121.0 \mathrm{~cm}$, with a mean of 13,13,438 (Wu et al., 2001) which is higher than that recorded in the present study. The difference in fecundity of C. hippurus observed from different geographical areas could be due to the variation of genetic and ecological

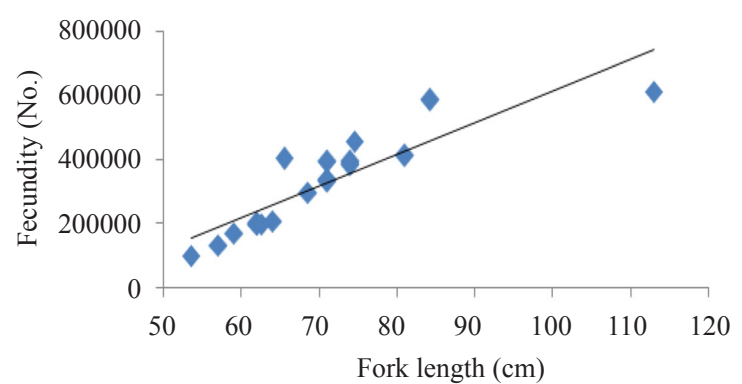

(a) factors, nutritional status, prevailing environmental conditions and variation in the methodologies used for the estimation of fecundity (Beacham and Murray, 1993; Unlo and Balci, 1993; Massuti and Morales-Nin, 1997). In the present study, the fecundity of $C$. hippurus increased with fork length, body weight and gonadal weight (Fig. 4) and is in agreement with earlier studies (Massuti and Morales-Nin, 1997; Wu et al., 2001; Zuniga-Flores et al., 2011).

The results of this study provide important aspects of reproductive biology of $C$. hippurus along the tropical Arabian Sea. The pattern of GSI and maturity stages suggests a peak spawning activity in August-September. Further, the incidence of spawning capable fishes all through the year in varied proportions implied that the spawning activity occurs throughout the year. The estimated fecundity varied from 100,298 eggs $(53.5 \mathrm{~cm}$ FL) to 615,267 eggs (113 cm FL) and has significant linear relationship with fork length, body weight and gonad weight. The biological information derived from the present study, on maturation, reproductive cycle, periodicity and fecundity of $C$. hippurus in the tropical Arabian Sea could be useful for developing appropriate management tools and conservation strategies for judicious exploitation of this commercially important fish species in Indian waters.

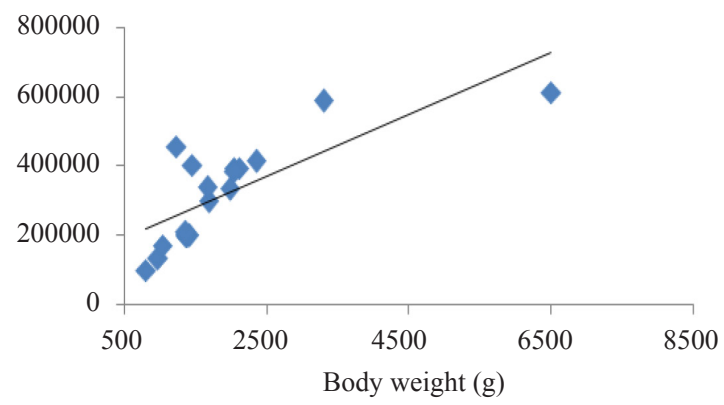

(b)

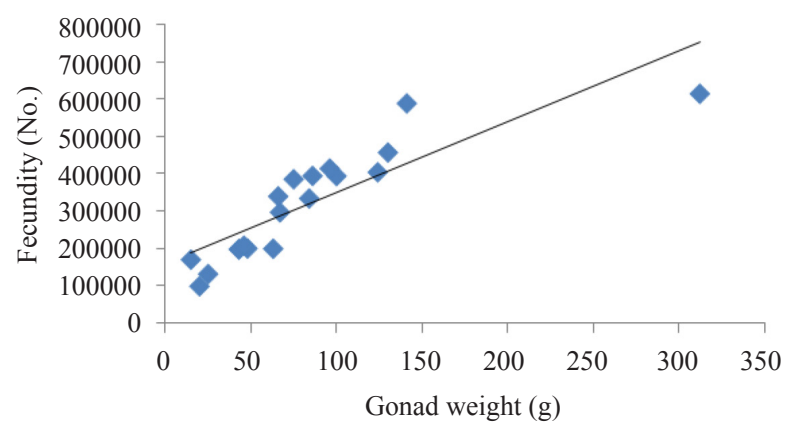

(c)

Fig. 4. Relationship between fecundity to (a) Fork length, (b) Body weight and (c) Gonad weight of C. hippurus along Karnataka coast, south-eastern Arabian Sea during August 2017-May 2018 


\section{Acknowledgements}

The facilities and constant support provided during the entire study period by the Dean, College of Fisheries, Mangaluru and the Scientist in-charge and staff of the Mangaluru Research Centre of ICAR-CMFRI, is duly acknowledged.

\section{References}

Alejo-Plata, C., Diaz-Jaime, P. and Salgado-Ugarte, I. H. 2011. Sex ratio, size at sexual maturity and spawning seasonality of dolphinfish (Coryphaena hippurus) captured in the Gulf of Tehuantepec, Mexico. Fish. Res., 110: 207-216. doi. org/10.1016/j.fishres.2011.04.008.

Arocha, F., Marcano, L. A., Larez, A., Altuve, D. and Alio, J. 1999. The fishery, demographic size structure and oocyte development of dolphinfish, Coryphaena hippurus, in Venezuela and adjacent waters. Sci. Mar., 63: 401-409. doi: 10.3989/scimar.1999.63n3-4401.

Bagenal, T. B. and Braum, E. 1978. Eggs and early life history. In: Bagenal, T. (Ed.), Methods of assessment of fish production in freshwaters, IBP Handbook 3, Blackwell Scientific, Oxford, UK, p. 165-201.

Beacham, T. D. and Murray, C. B. 1993. Fecundity and egg size variation in North American Pacific salmon (Oncorhynchus). J. Fish. Biol., 42: 485-508. https://doi. org/10.1111/j.1095-8649.1993.tb00354.x.

Beardsley, G. L. Jr. 1967. Age, growth and reproduction of the dolphin, Coryphaena hippurus in the straits of Florida. Copeia, 2: 441-451.

Bentivoglio, A. A. 1998. Investigations into the growth, maturity, mortality rates and occurrence of the dolphin (Coryphaena hippurus Linnaeus) associated with FADs in the Gulf of Mexico. M. Sc. thesis. University College of North Wales, Bangor, UK, $37 \mathrm{pp}$.

Brewton, R. A., Ajemian, M. J., Young, P. C. and Stunz, G. W. 2016. Feeding ecology of dolphinfish in the Western Gulf of Mexico. Trans. Am. Fish. Soc., 145(4): 839-853. https:// doi.org/10.1080/00028487.2016.1159614.

Brown-Peterson, N. J., Wyanski, D. M., Saborido-Rey, F., Macewicz, B. J. and Lowerre-Barbieri, S. K. 2011. A standardised terminology for describing reproductive development in fishes. Mar. Coast. Fish. Dyn. Manag. Ecosyst. Sci., 3: 52-70. https://doi.org/10.1080/19425120. 2011.555724

Burt, A., Kramer, D. L., Nakatsura, K. and Spry, C. 1988. The tempo of reproduction in Hyphessoberycon pulchripinis (Characidae), with the discussion of multiple spawning in fishes. Environ. Biol. Fish., 22: 15-27. doi :10.1007/ BF00000541.

Castro, J.J., Santiago, J.A., Hernandez-Garcia, V. and Pla, C. 1999. Growth and reproduction of the dolphinfish (Coryphaena hippurus and Coryphaena equiselis) in the Canary Islands,
Central East Atlantic (Preliminary results). Sci. Mar. 63(3-4): 317-325. doi:10.3989scimar.1999.63n3-4327.

Chatterji, A. and Ansari, Z. A. 1982. Fecundity of dolphin-fish, Coryphaena hippurus L. Mahasagar, 15(2): 129-133.

Cheung, W. W. L., Lam, V. W. Y. and Pauly, D. 2008. Modeling present and climate-shifted distribution of marine fishes and invertebrates. Fisheries Centre Research Reports. University of British Columbia, Vancouver, B. C., Canada. $72 \mathrm{pp}$.

CMFRI 2018. Marine fish landings in India 2018, Technical Report, ICAR-Central Marine Fisheries Research Institute, Kochi, India, p.16.

Collette, B.,Acero,A.,Amorim,A. F., Boustany,A., Canales, R. C., Cardenas, G., Carpenter, K. E., De Oliveira Leite Jr, N., Di Natale, A., Fox, W., Fredou, F. L., Graves, J., Vierahazin, F. H., Juan J. M., Minte, V. C., Miyabe, N., Montano, C. R., Nelson, R., Oxenford, H., Schaefer, K., Serra, R., Sun, C., Teixeiralessa, R. P., Pires, F. T. P. E., Uozumi, Y. and Yanez, E. 2011. Coryphaena hippurus. The IUCN Red List of Threatened Species 2011, e.T154712A4614989. doi: 10.2305/IUCN.UK.

Diaz-Jaimes, P., Uribe-Alcocer, M., Rocha-Olivares, A., Garcia-de-Leon, F. J., Nortmoon, P. and Durand, J. D. 2010. Global phylogeography of the dolphinfish (Coryphaena hippurus): The influence of large effective population size and recent dispersal on the divergence of a marine pelagic cosmopolitan species. Mol. Phylogenit. Evol., 57(3): 1209-1218. https://doi.org/10.1016/j.ympev.2010.10.005.

Erdman, D. S. 1976. Spawning patterns of fishes from the north-eastern Caribbean, Commonwealth of Puerto Rico, Agricultural and Fisheries Contributions. Official publication of the area of special services, 8(2): 1-34.

FAO 2019. Coryphaena hippurus (Linnaeus, species fact sheet 1758). Food and Agriculture Organisation of the United Nations. Rome, Italy. http://www.fao.org/fishery/ species/3130/en2019.

Furukawa, S., Ohshimo, S., Tomoe, S., Shiraishi, T., Nakatsuka, N. and Kawabe, R. 2012. Age, growth and reproductive characteristics of dolphinfish Coryphaena hippurus in the waters off west Kyushu, northern East China Sea. Fish. Sci., 78: 1153-1162. doi:10.1007/s12562-012-0557-6.

FWRI 2008. Dolphin-general facts. Fish and wildlife Research Institute, Florida. p. 55-59.

Gatt, M., Dimech, M. and Schembri, P. J. 2015. Age, growth and reproduction of Coryphaena hippurus (Linnaeus, 1758) in Maltese waters, Central Mediterranean. Medit. Mar. Sci., 16(2): 334-345. doi.org/10.12681/mms. 706 .

Guzman, H. M., Ferguson, E. D., Vega, A. J. and Robles, Y. A. 2015. Assessment of the dolphinfish Coryphaena hippurus fishery in Pacific Panama. Rev. Biol. Trop., 63(3): 705-716. doi:10.15517/rbt.v63i3.15487.

Hunter, J. R. and Macewicz, B. J. 1985. Measurement of spawning frequency in multiple spawning fishes. In: 
Lasker, R. (Ed.), An egg production method for estimating spawning biomass of pelagic fish: Application to the northern anchovy, Engraulis mordax. U. S. National Marine Fisheries Service, National Oceanic And Atmospheric Administration Technical Report, p. 79-94.

Hunter, J. R., Macewicz, B. J., Lo, N. C. H. and Kimbrell, C. A. 1992. Fecundity, spawning and maturity of female Dover sole Microstomus pacificus, with an evaluation of assumptions and precision. Fish. Bull., 90: 101-128.

Johnson, B., Johnson, N. and Finstad, A. G. 2013. Effects of temperature and food quality on age and size at maturity in ectotherms: An experimental test with Atlantic salmon. J. Anim. Ecol., 82: 201-210. doi.org/10.1111/j.1365-2656. 2012.02022.x.

King, M. 2007. Reviews of fisheries biology, assessment and management, Blackwell Publishing, Oxford, U. K., 382 pp. doi:10.1007/s11160-008-9090-1.

Lasso, J. and Zapata, L. 1999. Fisheries and biology of Coryphaena hippurus (Pisces: Coryphaenidae) in the Pacific coast of Colombia and Panama. Sci. Mar., 63: 387-399. doi:10.3989/scimar.1999.63n3-4387.

Maggio, T., Allegra, A., Andaloro, F., Pedro Barreiros, J., Battaglia, P., Butler, C. M., Cuttitta, A., Miguel, R. F. J., Freitas, R., Gatt, M., Saadet, K. F., Macias, D., Nicosia, A., Oxenford, H. A., Saber, S., Vasco Rodrigues, N., Yildiz, T. and Sinopoli, M. 2018. Historical separation and present-day structure of common dolphinfish (Coryphaena hippurus) populations in the Atlantic Ocean and Mediterranean Sea. ICES J. Mar. Sci., 76(4): 1028-1038. doi: 10.1093/icesjms/fsy174.

Massutí, E. and Morales-Nin, B. 1997. Reproductive biology of dolphinfish Coryphaena hippurus off the island of Majorca (western Mediterranean). Fish. Res., 30: 57-65. doi: 10.1016/S0165-7836(96)00562-0.

McBride, R. S., Snodgrass, D. J. G., Adams, D. H. and Rider, S. J. 2012. An indeterminate model to estimate egg production of the highly iteroparous and fecund fish dolphinfish (Coryphaena hippurus). Bull. Mar. Sci., 88(2): 283-303. doi: 105343/bms.2011.1096.

Molto, V., Hernandez, P., Sinopoli, M., Besbes-Benseddik, A., Besbes, R., Mariani, A., Gambin, M., Alemany, F., Morales-Nin, B., Grau, A. M., Caminas, J. A., Baez, J. C., Vasconcellos, M., Ceriola, L. and Catalan, I. A. 2020. A global review on the biology of the dolphinfish (Coryphaena hippurus) and its fishery in the Mediterranean Sea: Advances in the last two decades. Rev. Fish. Sci. Aquac. 28(3): 376-420. http://doi:10.1080/23308249.202 0.1757618 .

Murua, H. and Saborido-Rey, F. 2003. Female reproductive strategies of marine fish species of the north Atlantic. J. Northw. Atl. Fish. Sci., 33: 23-31. http://doi:10.2960/J.v33.a2.

Murua, H., Kraus, G., Saborido-Roy, F., Witthames, P. R., Thorsen, A. and Junquera, S. 2003. Procedures to estimate fecundity of wild collected marine fish species in relation to their reproductive strategy. J. Northw. Atl. Fish. Sci., 33: 33-54. http://doi:10.2960/J.v33.a3.

Olson, R. J. and Galvan-Magana, F. 2002. Food habits and comparison rates of common dolphinfish Coryphaena hippurus in the eastern Pacific Ocean. Fish Bull., 100 279-298.

Oxenford, H. A. and Hunte, W. 1983. Age and growth of dolphin Coryphaena hippurus, as determined by growth rings in otoliths. Fish. Bull., 84(4): 906-909.

Oxenford, H. A. 1985. The biology of the dolphinfish Coryphaena hippurus and its implications for the Barbadian fisheries. Doctoral thesis, University of the West Indies, Cave Hill, Barbados. p. 366.

Oxenford, H. A. 1999. Biology of the dolphinfish Coryphaena hippurus in the western central Atlantic: A review. Sci. Mar., 63(3): 277-301. doi: 10.3989/scimar.1999.63n3-4303.

Rajesh, K. M., Rohit, P. and Abdussamad, E. M. 2016. Fishery, diet composition and reproductive biology of the dolphinfish Coryphaena hippurus (Linnaeus, 1758) off Karnataka, south-west coast of India. Indian J. Fish., 63(4): 35-40. doi: 10.21077/ijf.2016.63.4.60190-06.

Rose, C. D. and Hassler, W. W. 1974. Food habits and sex ratios of the dolphin Coryphaena hippurus captured in the western Atlantic Ocean off Hatteras, North Carolina. Trans. Am. Fish. Soc., 103: 94-100.

Santos, A. C. L. D., Coutinho, I. M., Viana, D. D. L., Rego, M. G. D., Branco, I. S. L., Hazin, F. H. V. and Oliveira, P. G. V. D. 2014. Reproductive biology of dolphinfish, Coryphaena hippurus (Actinopterygii: Coryphaenidae), in Saint Peter and Saint Paul Archipelago, Brazil. Sci.Mar., 78(3):363-369. http://dx.doi.org/10.3989/ scimar.04013.08A.

Saroj, J. K., Koya, M., Mathew, K. L. and Tehseen, P. 2018 Reproductive biology and feeding habits of the common dolphinfish Coryphaena hippurus (Linnaeus, 1758) off Saurashtra coast, India. Indian J. Fish., 65(4): 44-49. doi: 10.21077/ijf.2018.65.4.74184-05.

Schwenke, K. L. and Buckel, J. A. 2008. Age, growth and reproduction of dolphinfish (Coryphaena hippurus) caught off the coast of North Carolina. Fish. Bull., 106: 82-92.

Sushanth, V. R. and Rajashekhar, M. 2014. Seasonal assessment of hydrographic variables and phytoplankton community in Arabian Sea waters of Kerala, South-west coast of India. Braz. J. Oceanogr., 62(4): 279-293. doi: 10.1590/S167987592014069906204.

Unlo, E. and Balci, K. 1993. Observation on the reproduction of Leuciscus cephalus orientalis (Cyprinidae) in Savur stream (Turkey). Cybium, 17(3): 241-250.

Vinod Kumar, M., Farejiya, M. K., Kiran, S. M., Sahu, K. C. and Rahulkumar, T. 2017. Observations on the food preferences, growth parameters and biological aspects of Coryphaena hippurus Linnaeus, 1758 exploited through 
the longline survey operations along the west coast of India. Int. J. Fish. Aquat. Stud., 5(2): 240-248.

Wu, C. C., Wei-Cheng, S. W. and Kawasaki, T. 2001. Reproductive biology of the dolphin fish Coryphaena hippurus on the east coast of Taiwan. Fish. Sci., 67: 784-793. doi: 10.1046/j.1444-2906.2001.00324.x.
Zuniga-Flores, M. S., Ortega-Garcia, S., Rodriguez-Jaramillo, M. D. C., Lopez-Martinez, J. and Lopez-Martinez 2011. Reproductive dynamics of the common dolphinfish Coryphaena hippurus in the southern Gulf of California. Mar. Biol. Res., 7: 677-689. https://doi.org/10.1080/11250 003.2013.845260. 